\title{
ISLAM DI PAPUA BARAT: \\ Tradisi dan Keberagaman
}

\author{
Ismail Suardi Wekke \\ Jurusan Dakwah STAIN Sorong, Papua Barat \\ Telp: 081315540777 \\ email: iswekke@gmail.com
}

\begin{abstract}
Papua is known as population of non muslim society, yet in fact, its muslim community has been established since 1512. Therefore, it is relevant to explore the existence of muslim in West Papua province nowdays. This study employs qualitative approach using grounded theory. In data collection, observation and in-depth interview were conducted. In addition, the main instrument was the researcher utilizing observation sheet and interview guide. The result shows three findings namely leadership and tradition, religiousity and diversity, and learning spirit. These findings means that the muslims in the region not only preserve their tradition but also try to maintain the harmony with other religions. This attitude did not arise spontaneously, there was a long history so that they can coexist with the others as a family.
\end{abstract}

Papua dikenal dengan populasi masyarakat non muslim, tapi fakta sebaliknya menunjukkan bahwa masyarakat Islam sudah terbentuk sejak tahun 1512. Oleh karena itu, menjadi relevan untuk melakukan eksplorasi keberadaan umat Islam di Provinsi Papua Barat dengan kondisi terkini. Penelitian ini menggunakan pendekatan kualitatif dengan jenis grounded theory. Dalam mengumpulkan data, pengamatan dan wawancara mendalam digunakan. Adapun instrumen utama adalah peneliti sendiri dengan didampingi pedoman observasi dan panduan wawancara. Penelitian ini menunjukkan tiga temuan yaitu kepemimpinan dan adat, keberagamaan dan keberagaman, dan semangat belajar. Temuan utama tersebut menunjukkan bahwa muslim di wilayah tersebut tidak saja berusaha mempertahankan tradisi mereka tetapi juga senantiasa mempertahankan harmoni beragama dengan umat lain. Sikap ini tidaklah muncul secara spontan, ada 
perjalanan sejarah yang panjang sehingga mereka bisa hidup berdampingan dengan yang lain sebagai sebuah keluarga.

Keywords: Papua Barat, tradition, multicultural, Islam, budaya

\section{Pendahuluan}

Ketika mengeja kata Papua, maka salah satu asosiasi kita adalah mayoritas penduduk Papua menganut agama Kristen. Bahkan stigma ini juga semakin menguat ketika kemudian ada usulan yang mengemuka untuk mengukuhkan Manokwari sebagai kota Injil. Merupakan tandingan atas disebutnya Aceh sebagai Mekkah dan Makassar sebagai serambi Medinah. Tentu bahwa asumsi itu benar adanya, namun tidak relevan. Di mana suku Kokoda, Irarutum, Arandai sebagai bagian dari penduduk lokal Papua. Mereka mayoritas menganut agama Islam secara turun temurun. Justru Islam lebih dulu masuk ke tanah Papua dibanding dengan agama lain. Saat itu, tahun 1512 terbangun komunitas muslim di Misool setelah kontak dengan pedagang Seram dan Bugis, begitu pula intelektual Banda (Muller, 2008: 88). Karakteristik wilayah yang khas dengan kontur wilayah pantai dan pegunungan kemudian memberikan dampak bagi kehidupan masyarakat. Pada prosesnya juga memberikan pengaruh terhadap identitas beragama.

Sementara warga Papua lainnya, juga bukan semata-mata warga Papua yang berasal dari etnis Papua semata. Tetapi keberadaan warga dari etnis lain di Indonesia juga sangat signifikan. Mulai dari Batak sampai Menado. Bahkan suku Bugis, Makassar, Buton ditambah dengan suku-suku yang berasal dari Maluku dan Maluku Tenggara. Di antara para pendatang mayoritas beragama Islam. Kedatangan para penduduk ini tentu tidak dapat melepaskan diri dari agama yang dipeluk. Di saat sebelum menginjak daratan Papua, sudah terbentuk sejak awal kesadaran beragama yang diperoleh dari lingkungan masing-masing. Pada saat berada di komunitas, interaksi antar kelompok senatiasa memasukkan elemen agama sebagai salah satu unsur.

Ini relevan dengan agama dalam pandangan Geertz bahwa keimanan memberikan aturan ketertiban secara sosial. Sekaligus memberikan makna bagi dunia terutama dalam wilayah transedental. Agama akan memberikan jawaban terhadap kegelisahan manusia sehingga kemudian menemukan sebuah pegangan hidup untuk dijadikan sebagai prinsip. Ini juga dalam pendapat pakar lain dengan uraian bahwa agama merupakan petunjuk moral. Perilaku pemeluk agama kemudian dikontrol (Giddens, 1989: 452). Lalu wujud pemberlakuan pranata dan norma agar para penganut mengikuti 
garis yang telah ditetapkan agama. Tentu keinginnya bahwa manusia akan dituntun menuju kepada keselamatan dan mengikuti jalan yang benar. Agama sesungguhnya memiliki peran dalam pembentukan kecendrungan etnisitas. Kecendrungan ini kemudian memberikan dampak bagi pencerahan pada fase selanjutnya menjadi siklus kebudayaan (Al Alusi, tt: 159-160).

Islam sebagai agama, tidak dapat dilepaskan sebagai bagian sosial dari kebudayaan masyarakat (Abdullah, 1996: 30-31). Dengan mengambil tempat di masyarakat, maka agama itu menemukan elaborasi diri. Maka, dalam keseharian kepercayaan menjadi instrumen sehari-hari. Dalam masyarakat Indonesia, identitas budaya lokal menjadi satu dengan keberadaan Islam. Tidak saja Islam menampakkan diri dalam bentuk Arab dan Timur Tengah, tetapi pemeluk Islam kemudian mengelaborasi diri dengan adat yang ada sepanjang tidak menjadi penghalang untuk menjadi muslim yang utuh. Ketika Islam datang, masyarakat Indonesia telah mencapai kebudayaan yang tidak bisa disebut sebagai kebudayaan tingkat rendah. Dengan pertemuan dua kebudayaan maka ada proses akulturasi sehingga terwujud bentuk kebudayaan baru yang masing-masing tidak menafikan keberadaan budaya yang sudah wujud sebelumnya. Dari proses ini, Islam menemukan bentuk yang berbeda dengan kawasan dunia Islam yang lain. Justru pengalaman keagamaan dalam hubungannya dengan tradisi lokal merupakan pengalaman yang unik bagi seorang pemeluk agama (Mulkan, 2001: 104).

Oleh karena itu, penelitian ini berupaya mengungkapkan pembahasan tentang keberadaan Islam sebagai pandangan hidup di Papua Barat. Fokus pembahasan diarahkan untuk menjawab pertanyaan penelitian "bagaimana perilaku sosial yang menghubungkan Islam dengan kondisi setempat di Papua Barat?"

\section{Metode Penelitian}

Dalam menjawab masalah penelitian ini, dilakukan penekanan pada proses pencarian jawaban atas pertanyaan-pertanyaan yang muncul. Penelitian ini lebih mengutamakan kepekaan terhadap ekologis dan keutuhan, memusatkan perhatian terhadap fungsi serta menekankan pada penjelasan (Taylor, 1993:54). Sehingga, penelitian ini menggunakan pendekatan kualitatif dengan menerapkan grounded theory. Di mana pengembangan teori dilakukan setelah melakukan pengumpulan data dilanjutkan dengan analisis (Strauss dkk, 1994: 273). Untuk itu, selama pengumpulan data dilakukan beberapa tahap sejak 2010 sampai 2012. Kategori dan data yang telah dikumpulkan 
diperbandingkan secara terus menerus. Dengan bertambahnya data, maka kemudian teori terbentuk. Proses inilah kemudian menjadikan penelitian ini bisa menemukan pengembangan teori. Ada lima langkah yang dilakukan yaitu pertama pengumpulan data. Kedua, analisis data berdasarkan kategori. Ketiga, ketika terjadi penambahan data, maka analisis tetap dilakukan dalam rangka menemukan kategori. Keempat, mengajukan hipotesis, termasuk menemukan hubungan antara butir-butir yang ada. Terakhir, pertimbangan hipotesis untuk penelitian lanjutan sampai terbentuknya teori.

Pengumpulan data penelitian dilakukan di Provinsi Papua Barat. Hanya Kabupaten Teluk Wondama yang belum diobservasi, tetapi kabupaten dan kota lain semuanya sudah dikunjungi. Namun demikian, walaupun observasi lapangan belum dilakukan dalam skala Kabupaten Teluk Wondama tetapi wawancara mendalam untuk mendapatkan data-data berkenaan dengan Teluk Wondama sudah dilaksanakan sebanyak dua kali. Narasumber terdiri atas beberapa pegawai kementerian agama, ketua Majelis Ulama dan tokoh masyarakat tidak saja dari agama Islam tetapi juga dari kalangan Kristen dan Katolik. Dengan demikian, penelitian ini telah berupaya menggali data dari subyek penelitian secara menyeluruh.

Untuk lokasi suku Kokoda bermukim di Kabupaten Sorong, Kabupaten Sorong Selatan dan Kota Sorong. Sementara untuk suku Arandai di kabupaten Teluk Bintuni. Untuk suku Arguni di Kabupaten Kaimana. Sementara di Kokas sebagai salah satu daerah awal yang memeluk Islam ditelusuri dengan berusaha mengadakan observasi secara menyeluruh. Sekaligus melakukan wawancara dan pengecekan keabsahan data secara berulang. Proses triangulasi sebagai proses keabsahan data dilaksanakan dengan dua tahap. Pertama, ketekunan pengamatan dengan melakukan pengecekan kembali secara rinci dan teliti terhadap pengamatan sebelumnya. Data-data yang sudah didapatkan diteliti dan dikonfirmasi dengan subyek penelitian yang lain. Langkah ini untuk memastikan bahwa data yang didapatkan adalah data yang valid. Kedua, pengecekan sejawat dan pakar. Konsultasi, diskusi dan pengecekan diajukan dalam diskusi kelompok bersama rekan-rekan sejawat. Selanjutnya bahan yang sama diajukan kepada guru besar dan pakar penelitian untuk mendapatkan masukan dan kekurangan penelitian. Langkah-langkah ini ditempuh berdasarkan kriteria teori grounded (Charmaz, 1983: 109-126).

Terakhir, penelitian ini tidak terlepas dari keterbatasan-keterbatasan. Faktor keterbatasan utama terletak pada kondisi dimana tidak dapat dilakukan generalisasi pada subjek penelitian dan kondisi yang lain. Konteks wilayah, suku 
dan adat istiadat yang berbeda-beda antara suku dan marga sehingga sekali lagi generalisasi bukanlah menjadi faktor bagi keberadaan Islam di Papua Barat. Walaupun perpanjangan waktu pengumpulan data telah dilakukan sampai Desember 2012 tetapi tetap saja keterbatasan menjadi bagian penelitian ini, di mana peneliti merupakan salah satu instrumen utama dalam pengumpulan data, disamping instrumen pengumpulan data yang lain tetap digunakan yaitu panduan wawancara dan pedoman observasi.

\section{Hasil Penelitian}

Sebagai wilayah yang memiliki hutan, laut dan pegunungan, maka Papua memiliki daya tarik bagi banyak pendatang sehingga kemudian bermukim mulai dari Sorong di barat daya sampai ke Tanah Merah di Merauke, bagian timur Papua. Dengan kedatangan para orang luar menjadikan Papua sebagai Indonesia kecil. Dimana tidak ada dominasi suku dan agama tertentu. Bahkan dalam pergaulan masyarakat di Fakfak, terkadang satu keluarga terdiri atas Kristen, Katolik dan Islam. Istilah "Satu Tungku Tiga Batu" digunakan untuk mewakili tradisi ini di Fakfak. Sementara di Raja Ampat digunakan istilah "Satu Rumah Empat Pintu". Kondisi tersebut tetap bukan menjadi masalah, dimana agama dijadikan sebagai identitas diri dan hubungannya dengan Tuhan. Sementara hubungan kekeluargaan yang cenderung komunal membuat hubungan antar keluarga tetap akrab. Keluarga yang satu dengan keluarga yang lain senantiasa saling membantu tidak saja dalam keperluan sehari-hari, bahkan dalam acara keagamaan secara bersama-sama mereka bergotong royong mempersiapkan acara tersebut. Sehingga walaupun berbeda agama, tetapi tetap dalam satu rumpun keluarga, maka kemudian ini dipandang kekerabatan menjadi acuan utama dan tidak memperhitungkan agama sebagai atribut. Ikatan kekeluargaan yang biasa juga disebut marga lebih penting dari pilihan beragama.

Tidak saja Fakfak dan Raja Ampat tetapi ini menyebar hingga ke Wondama dan Bintuni, kebiasaan perbedaan pilihan beragama dalam satu keluarga bukan hal yang luar biasa. Masing-masing anggota keluarga secara sadar sejak awal bahkan mereka boleh memilih jalan agama yang berbeda. Tetapi ikatan keluarga harus tetap utuh dan dipertahankan. Hubungan pertalian darah senantiasa tetap utama. Namun ketika pada urusan memilih keyakinan beragama, maka itu merupakan hak individual. Sementara keluarga yang lain tidak mempermasalahkan pilihan itu. Justru mendukung dan memberikan pengakuan. Sejak awal tidak pernah dikenal pengucilan terhadap perbedaan agama. Ada personalitas dalam keimanan yang menjadi kesepakatan sosial. 
Ukuran yang dipakai bukanlah pada aspek agama tetapi semata-mata pada ikatan keluarga besar.

Dalam kegiatan MTQ (Musabaqah Tilawatil Quran) tingkat Provinsi Papua Barat 2012, ketua panitia dijabat seorang muslim. Adapun wakil ketua didampingi oleh seorang pastor dan seorang lagi pengurus Persatuan Gereja Indonesia (PGI). Mereka bersama-sama duduk sebagai panitia. Lalu ketika acara pembukaan dan penutupan, anak-anak muda yang tergabung dalam paduan suara di gereja menyumbangkan lagu dan mengiringi prosesi acara yang berlangsung. Tentu kerjasama dan soliditas yang ada seperti ini menjadikan dialog antar umat beragama sudah menemukan kontekstualisasi dan relevansinya dalam masyarakat yang beranekaragam. Tradisi gotong royong dalam mewujudkan MTQ ini dimulai sejak MTQ tahun 2006 yang dilaksanakan di Kabupaten Manokwari. Umat Kristiani sejak awal menawarkan diri untuk turut membantu persiapan dan penyelenggaran acara. Dalam perjalanan waktu, model ini kemudian dicoba diadaptasi dalam pelaksanaan acara-acara berikut. Walaupun kegiatan ini murni adalah untuk kepentingan umat Islam, tetapi secara meluas, MTQ dijadikan sebagai ajang kerjasama umat beragama. Sehingga tidak terbatas di kalangan muslim saja.

Bagi suku-suku di Papua, ketika Islam diterima sebagai status agama, salah satu faktor penting penerimaan keyakinan itu adalah prinsip Islam memandang manusia atas dasar persaudaraan dan kesamaan. Ini kemudian membuat Islam diminati dan memperoleh simpati. Beberapa kawasan, seperti pasar Remu di Sorong, Aimas di Kabupaten Sorong, atau Pasar Lama di Kaimana senantiasa menerima saudara baru dengan adanya muallaf yang menerima hidayah untuk mengikrarkan diri sebagai seorang muslim. Lalu ketika ada ikrar syahadat maka spontanitas biasanya terjadi. Pengusahapengusaha muslim memberikan tanda mata berupa pakaian muslimah atau peralatan shalat beserta Quran bagi yang baru saja mengikrarkan syahadat. Dukungan bagi muallaf senantiasa ditawarkan. Sekaligus juga memberikan pekerjaan bagi kelangsungan hidup sang muallaf.

Identitas lain, umat Islam di Papua Barat adalah sikap tolong menolong dan gotong royong. Pembangunan masjid termasuk kemakmuran masjid dilaksanakan dengan sistem gotong royong. Di awal pembangunan biasanya takmir majsid mengumumkan kebutuhan material dan biaya pengerjaan termasuk ongkos lainnya. Informasi ini disebarkan setiap kesempatan lalu kemudian secara bersama-sama mereka akan memberikan kontribusi sesuai dengan kondisi masing-masing. Ketika penelitian dilaksanakan, salah satu 
masjid yang diobservasi adalah Masjid Quba, Pasar Sentral Bintuni. Dalam pengerjaannya umat Islam senantiasa bahu membahu. Masing-masing pihak membantu sesuai dengan kemampuan masing-masing. Bahkan, ada yang membantu dengan menyiapkan makanan bagi warga yang sementara bergotong-royong.

Kawasan pasar selalu memiliki masjid yang representatif. Tidak saja bangunan, tetapi kebutuhan akan imam dan bilal senantiasa dijaga demi menjamin shalat berjamaah yang kondusif. Ini dapat terlaksana karena pedagang pasar secara bersama-sama berkontribusi dalam pembangunan masjid. Bahkan masjid Quba di kota Sorong, masjid tidak saja mengelola masjid sebagai tempat ibadah. Masjid mengembangkan program dengan mengelola madrasah yang terdiri atas sekolah dasar dan sekolah menengah. Pembebasan biaya sudah dilaksanakan bahkan sebelum program pemerintah menerapkan biaya operasional sekolah (BOS). Inovasi masjid Quba kemudian menjadi inspirasi bagi masjid lain untuk menyediakan sarana belajar bagi umat Islam. Kemudian inovasi ini diikuti masjid al jihad dan masjid Akbar di kota Sorong, demikian pula masjid Pantai Seram di Kaimana, masjid Pasar Baru dan masjid al Fatihah di Teluk Bintuni. Setelah pembangunan selesai, masjid juga diupayakan dengan melakukan kegiatan-kegiatan yang berorientasi pada peningkatan kapasitas jamaah yang dijalankan dengan berbasis masjid. Ketika di bulan Ramadhan, jamaah juga bergotong-royong menyediakan buka puasa dan makan malam. Demikian pula dilaksanakan shalat lail (malam) pada sepuluh malam terakhir Ramadhan.

Pada urusan pendidikan dan pernikahanpun umat Islam senantiasa mau saling membantu. Ketika ada salah seorang warga yang tidak mampu untuk menempuh pendidikan ke tingkat yang lebih tinggi tetapi tidak mempunyai biaya. Sementara sang anak mampu secara intelektual dan juga memiliki semangat belajar. Ini kemudian dicarikan secara bersama-sama oleh komunitas untuk dicarikan penyelesaian masalah. Bahkan dalam urusan pernikahan. Ketika ada pasangan yang tidak mampu dalam penyelenggaraan syarat-syarat wajib dalam pernikahan, maka warga secara bersama-sama dengan digerakkan semangat kebersamaan senantiasa membantu sang pasangan ini.

Salah satu pola yang dikembangkan muslim di Papua Barat, sekolah agama juga mengelola masjid yang dimanfaatkan juga masyarakat sekitar sekolah. Seperti MAN Model Sorong, SMA Yapis Kaimana, Perguruan Islam Muhammadiyah Bintuni. Masjid-masjid sekolah ini membangun masjid dengan dukungan umat Islam setempat bersama dengan orang tua siswa. Di samping 
menjadi bagian pembinaan siswa masjid sekolah juga menjadi bagian kegiatan masyarakat. Di waktu sekolah, masjid berfungsi sebagai bagian kelas. Tetapi di luar waktu sekolah, masjid difungsikan dan turut dikelola masyarakat. Sinergitas ini menjadi salah satu pendukung aktivitas keberagamaan umat Islam.

Secara khusus, muslim di Papua Barat dapat digambarkan ke dalam tiga hal yaitu kepemimpinan dan adat, keberagamaan dan keberagaman, dan semangat belajar.

\section{Kepemimpinan dan Adat}

Suku Kokoda terbagi atas dua jika dilihat dari wilayah mukim dan pembauran. Pertama, suku Kokoda yang tinggal di daerah asal dan tidak berbaur dengan pendatang. Wilayah yang ditinggali semata-mata didiami dari suku Kokoda. Sementara itu, kategori kedua dimana suku Kokoda yang tinggal di kota sebagai tempat perantauan. Secara umum dengan tinggal di kota, maka mereka kemudian akan berbaur dengan warga lain baik pendatang maupun suku lain Papua. Baik yang bermukim maupun yang merantau selalu mengangkat seorang pemimpin yang mereka sebut dengan kepala suku. Melalui kepala suku inilah, perselisihan ataupun keperluan bersama disuarakan. Sekaligus jika ada kepentingan pemerintah atau pihak luar terkait dengan suku Kokoda akan berkomunikasi dengan kepala suku. Bahkan ketika ada perselisihan antar anggota, kriminalitas yang dilakukan sesorang, maka kepala suku kerap dimintai untuk melakukan koordinasi dan komunikasi.

Kepemimpinan terbagi atas dua. Kepemimpinan adat dan kepemimpinan agama. Kepala suku khusus memimpin pada persoalan adat dan kehidupan sehari-hari. Sementara untuk kepemimpinan agama dijabat oleh imam masjid, pegawai kementerian agama atau guru mengaji. Urusan-urusan adat sepenuhnya menjadi kewenangan para petua adat. Secara bersamaan kepemimpinan adat dan juga pemimpin agama senantiasa bekerja sama dalam urusan sosial masyarakat. Sebagai contoh, urusan pernikahan dilaksanakan kedua pemimpin tersebut. Ketika mengurus persiapan akad nikah, mahar dan saksi pernikahan maka sepenuhnya menjadi kewenangan imam. Tetapi untuk perhelatan jamuan, prosesi pernikahan dan juga hiasan pengantin ditangani oleh bagian adat.

Dalam kepemimpinan politik, umat Islam menjadi mitra bagi kalangan agama lain. Rahimin Katjong menjadi wakil gubernur Provinsi Papua Barat dua periode, dengan periode yang kedua masa jabatan 2012-2017. Sementara di kota Sorong Fahimah Iskandar menjadi wakil walikota periode yang sama 
dengan gubernur. Adapun wakil bupati yang lain yaitu Suka Rahardjo di kabupaten Sorong, di kabupaten kaimana, di kabupaten Teluk Bintuni diduduki Bahmuddin Fimbay. Sementara bupati dijabat di kabupaten Fakfak oleh Muahmmad Uswanas. Bahkan di kabupaten Kaimana periode sebelumnya bupati dijabat Ahmad Hasan, muslim kelahiran Kaimana. Sementara Inda Arfa menjabat wakil bupati di Raja Ampat. Ketika pemilihan legislatif 2009, baik di tingkat kabupaten dan kota maupun provinsi, agama tidak dijadikan sebagai isu yang krusial untuk mempengaruhi pemilih. Sehingga calon legislatif muslim juga mendapatkan kepercayaan dari masyarakat non muslim untuk duduk sebagai anggota legislatif di DPRD Provinsi Papua Barat maupun di DPRD kota dan kabupaten.

\section{Keberagamaan dan Keberagaman}

Toleransi dan penghargaan terhadap agama yang berbeda senantiasa di bangun di pelbagai tingkatan komunitas umat Islam. Perbedaan agama bukanlah menjadi masalah penting dalam pandangan masyarakat. Agama dipandang tidak lebih penting dibanding dengan keluarga. Dalam satu rumpun keluarga biasanya terdiri dari pelbagai agama. Di saat masing-masing keluarga merayakan hari besar perayaan agama, maka keluarga yang lain turut membantu keluarga yang merayakan acara tersebut. Demikian pula sebaliknya, keluarga non muslim membantu disaat perayaan agama Islam. Mereka sudah mengerti konsep-konsep tentang puasa, larangan memakan babi atau hewan tertentu. Di tengah kesepahaman tersebut, mereka tetap berusaha menjalankan agama sesuai dengan iman masing-masing.

Perbedaan agama yang ada dalam keluarga tidak menghalangi bekerja sama. Demikian pula perbedaan ini justru bukan menjadi pemecah belah tetapi sebaliknya justru menjadi penguat ikatan kekeluargaan. Sebagaimana observasi yang dilaksanakan selama perayaan idul fitri dan natal Tahun 2011 dan 2012. Keluarga yang beragama Kristen dan Katolik turut membantu keluarga yang merayakan idul fitri. Termasuk mengunjungi dan membantu anggota keluarga selama perayaan berlangsung. Demikian pula keluarga yang beragama Islam membantu keluarga lain ketika perayaan natal. Ini menunjukkan bahwa agama bukan dijadikan sebagai penghalang untuk tetap menjalin komunikasi. Justru pertalian darah dan keluarga yang lebih mengemuka untuk saling membantu dan tidak mempersoalkan pilihan identitas komunikasi yang berhubungan dengan kepercayaan. Bahkan di Fakfak, bangunan rumah orang tua sengaja dibuat oleh anak-anaknya dengan ruangan tengah yang agak luas. Ini untuk 
menjadikan rumah orang tua sebagai tempat berkumpul keluarga besar. Tidak memandang agama apapun yang merayakan hari besar dan hari suci. Tetapi keluarga secara bersama-sama bergotong royong untuk memberikan dukungan bagi perayaan agama anggota keluarga.

\section{Semangat Belajar}

Dalam beberapa perguruan, lembaga pendidikan yang didirikan kalangan muslim di dalamnya juga turut serta belajar penganut agama lain. Sebaliknya dalam lembaga pendidikan yang dikelola non muslim juga ada kalangan muslim yang belajar. Ini didorong faktor keterbatasan lembaga pendidikan. Tidak sebatas itu, faktor lain yang mendominasi adalah semangat untuk belajar. Sebagaimana di Pulau Namatota, Kaimana, lembaga pendidikan Protestan justru mengajarkan pendidikan agama Islam. Sebelum diundangkan kewajiban mengajarkan agama sesuai dengan kepercayaan seorang peserta didik, Namatota sudah melaksanakan. Bahkan lembaga pendidikan yang dijalankan Protestan justru tumbuh dan berkembang di tengah-tengah kampung muslim. Partisipasi pendidikan Protestan dan keikutsertaan muslim dalam proses pendidikan tersebut justru saling bersinergi. Ketika akses pendidikan yang sulit untuk dijangkau, maka justru dengan tidak mementingkan identitas agama. Kalangan Protestan telah menyediakan sarana pendidikan. Demikian muslim di Namatota tidak mempersoalkan penyedia proses pendidikan. Justru semangat belajar menjadi yang utama demi memenuhi kebutuhan akan ilmu pengetahuan dan keterampilan.

Untuk mewadahi keterbatasan, ada juga kalangan suku Kokoda di Sorong yang mendirikan lembaga pendidikan yang diberi nama Emeyodere. Perguruan ini mengelola pendidikan formal SD dan SMP. Sementara itu, keterlibatan dalam pendidikan secara meluas ditekuni oleh berbagai organisasi masyarakat. Diantaranya Muhammadiyah, NU, Yapis. DDI, DDII, Hidayatullah, Darul Istiqomah. Secara khusus lembaga pendidikan yang meluas dan berada di tiap kabupaten adalah Yapis dan Hidayatullah. Demikian pula NU sudah membentuk lembaga yang khusus mengurusi pendidikan yaitu al Ma'arif. Sementara amal usaha pendidikan Muhammadiyah tersebar mulai dari taman kanak-kanak sampai ke perguruan tinggi. Tahun 2012 nama Universitas Muhammadiyah Sorong digunakan sebagai alih status dari Universitas Muhammadiyah al Amin (Unamin). Di Aimas berdiri STKIP Muhammadiyah. Sementara di Manokwari, Yapis mendirikan Sekolah Tinggi Agama Islam (STAI) Yapis Manokwari. Perguruan tinggi tersebut tidak saja melayani umat Islam tetapi 
sekaligus menerima mahasiswa dari kalangan non-muslim.

Begitu pula partisipasi pendidikan tidak terbatas di kalangan usia sekolah saja. Beberapa kelas terselenggara dalam rangka peningkatan kualifikasi guruguru dilaksanakan secara rutin oleh masing-masing perguruan tinggi. Kalaulah bukan karena semangat belajar, maka proses ini akan berhenti di tengah jalan. Peserta umumnya berasal dari pulau-pulau yang jaraknya tempuhnya melebihi 24 jam ke tempat pendidikan. Diantara peserta berasal dari Inawatan dan Teminabuan di Sorong Selatan, Misool di Raja Ampat. Demikian pula beberapa kelas yang dilaksanakan untuk mewadahi semangat belajar mahasiswa yang berasal dari kalangan pedagang kaki lima. Beberapa diantaranya justru memiliki anak yang sementara juga menuntut ilmu di perguruan tinggi. Hanya saja berbeda semester. Hambatan usia, biaya, jarak, tidak diperhitungkan lagi. Semata-mata dalam rangka mengejar ilmu dan juga status sosial.

Semangat belajar dalam bentuk yang lain ditunjuk kaum muslimin ketika datangnya bulan suci Ramadhan. Mereka kemudian secara gotong royong mengundang dai dari wilayah lain untuk memberikan ceramah sebulan penuh sepanjang puasa. Selain ceramah tarawih juga pengajian yang khusus membahas kitab tertentu setelah sholat shubuh. Demikian juga imam untuk salat tarawih. Badan Dakwah Islam (BDI) dibentuk di beberapa perusahaan swasta antara lain Pertamina dan Petrochina. Secara rutin untuk keperluan shalat jumat, peringatan hari besar Islam, sahalat tarawih dan kepentingan ibadah lain organisasi yang digerakkan dengan dana karyawan berupaya untuk menghadirkan kegiatan-kegiatan dalam memberikan pencerahan umat. Dai khusus setiap kegiatan itu diorganisir BDI. Termasuk kegiatan ini mencapai pulau-pulau dimana dilakukan eksplorasi minyak seperti di Pulau Kasim dan Matoa. Beberapa masjid seperti masjid Quba, masjid al Jihad dan masjid al Taubah menyelenggarakan qiyam al lail (shalat malam) selama sepuluh terakhir di malam Ramadhan. Imam untuk memimpin jamaah sepanjang pelaksanaan qiyam al lail ini didatangkan khusus dari pulau lain.

Uraian ini menunjukkan adanya semangat belajar, termasuk untuk mendalami ilmu agama. Kesempatan di bulan Ramadhan senantiasa menjadi wahana untuk belajar. Sebagaimana di masjid al Fitrah Kota Sorong, masjid mengundang guru agama tamatan pesantren dari Makassar untuk mengajar satu kitab khusus seusai shalat shubuh. Sementara satu ustadz yang lain juga tetap menyampaikan ceramah ramadhan sebelum pelaksanaan shalat tarawih. Beberapa organisasi keislaman seperti NU dan Muhammadiyah juga menyelenggarakan pengajian secara rutin setiap hari ahad. Organisasi seperti 
Majelis Ulama Indonesia (MUI), Badan Amil Zakat Daerah (BAZDA), Badan Komunikasi Pemuda Remaja Masjid (BKPRMI), Ikatan Cendekiawan Muslim Indonesia (ICMI) menyelenggarakan acara pelatihan secara rutin dalam rangka penguatan kapasitas di lingkungan masing-masing.

\section{Pembahasan}

Salah satu pandangan dikemukakan bahwa daerah-daerah di barat Papua serta wilayah laut sudah tunduk kepada Sultan Bacan yang saat itu beragama Islam (Arnold, 1995: 402-404). Melalui pedagang-pedagang muslim, maka tanah Papua sudah mengenal Islam secara keseluruhan pada abad XVI. Tahun $1606 \mathrm{M}$, pemuka-pemuka masyarakat sudah menerima Islam sebagai agama. Pulau seperti Waigeo, Misool, Waigama yang berada di sebelah barat laut Papua sudah membantu kerajaan Bacan untuk meluaskan pengaruhnya ke Onin yang saat ini masuk dalam adminsitrasi wilayah Kabupaten Fakfak. Beberapa sarjana juga mencatat ada persaingan antara Ternate dan Tidore dalam memperebutkan pengaruh terhadap Raja Ampat (Widjojo, 2009: 14). Dalam salah satu catatan menunjukkan bahwa hubungan Tidore dengan Raja Ampat dilakukan melalui perwakilan (Widjojo, 2009: 20). Bahkan secara rutin Raja Ampat menyerahkan upeti berupa makanan, budak, perahu perang (kora-kora), kacang tanah, rempah-rempah, kulit, penyu dan juga burung cendrawasih.

Sementara itu, catatan lain menunjukkan bahwa perdagangan Tidore, Seram dan Ternate sudah menguasai Raja Ampat pada 1662 (Onim, 2006: 32). Sehingga perkembangan agama Islam yang dibawa oleh para pedagang dari tiga kawasan itu tidak saja ke Kepulauan Raja Ampat tetapi mencapai Sorong dan Fakfak. Penyebaran ini kemudian menjadi awal tradisi Islam (Andaya,1993: 30). Kehadiran Islam mempengaruhi budaya lokal, termasuk percampuran dengan budaya Melayu. Pulau Salawati dan Misool merupakan diantara dua pulau yang menerima Islam secara keseluruhan. Dengan persentuhan budaya lain, maka penduduk Papua kemudian mulai budaya yang terintegrasi secara sosial dengan budaya lain. Termasuk sistem pengetahuan yang dikembangkan oleh para pedagang. Termasuk hadirnya lembaga-lembaga sosial yang didukung secara penuh baik para pedagang maupun penduduk.

Hasil penelitian menunjukkan bahwa agama merupakan pilihan setiap individu dan tidak ada penentangan individu lain dari keluarga jika ada pilihan yang berbeda. Tentang mekanisme sosial ini mungkin banyak hal yang terjadi secara natural. Tetapi jika perlu menyebut satu hal, maka itu adalah komunikasi. 
Ini yang paling sering ditempuh individu dalam kehidupan sehari-hari ketika pemaknaan terhadap agama dapat disebarkan kepada pihak lain, maka akan terbentuk opini tertentu di kalangan masyarakat. Fenomena ini dapat diejlaskan bahwa setiap diskursus yang membumi selalu saja dimulai dari komunikasi (Habermas, 1983: 103). Ini dapat berarti bahwa ada pihak-pihak yang senantiasa mengkomunikasikan diskursus tersebut secara sistematis. Sehingga ide yang ada dapat diterima. Setelah sebelumnya hanya merupakan ide biasa saja, maka melalui pola komunikasi akan menjadi truth dan rightness.

Berbeda dengan penelitian yang justru menemukan keberadaan muslim minoritas sebagai objek prejudis, kecurigaan, pelecehan dan pelbagai bentuk diskriminasi lainnya (Weller, 2006: 295-325). Pada kondisi seperti ini menjelaskan bahwa ada dua hal yang menjadi pilihan yaitu perilaku destruktif atau mencari komunitas yang dirasa sesuai dengan karakter kehidupan (Bradford, 2008: 119). Sehingga dalam lingkungan sosial seperti itu, diperlukan kehadiran sebuah lembaga yang mampu memberikan pencerahan sekaligus pendampingan. Respon seperti ini ditunjukkan oleh muslim Amerika yang dengan wujudnya lembaga seperti Islamic Circle of North America (ICNA) yang berdiri tahun 1971 dan Islamic Society of North America (ISNA) mulai beraktivitas tahun 1981. Kedua lembaga tersebut memberikan layanan dan usaha untuk mempraktikkan Islam sebagai jalan hidup (Moore, 2007: 123-124). Walaupun demikian, penelitian ini menunjukkan bahwa ada kesamaan antara penelitian Weller, Bradford dan Moore. Muslim selalu berusaha untuk mempertahankan ajaran Islam walaupun dalam kondisi tidak leluasa untuk mengekspresikan keyakinan agama. Dapat dilihat bahwa ada upaya untuk mempertahankan identitas sekaligus tantangan integrasi dalam lingkungan yang ada.

Walaupun dalam kondisi minoritas tetapi muslim Papua senantiasa mendapatkan hak-hak individual. Penelitian ini menunjukkan tidak saja kebebasan beragama tetapi keluasan dalam kedudukan politik juga tidak dibatasi. Akses dan kesempatan untuk berpartisipasi selalu saja terbuka. Bahkan sampai pada posisi penting sekalipun. Ini bisa berarti bahwa, walaupun menghadapi problematika keadaan tetapi tidak mengalami kendala yang substansial. Ada esensi pada praktik konsep kesempatan bersama. Oleh karena itu, perbedaan perlakuan bukan menjadi isu yang utama sebab ada pengakuan dan kesempatan. Adapun penelitian yang justru menunjukkan sebaliknya dimana komunitas muslim tidak mendapatkan kesempatan yang sama (Loobuyck, 2005: 113-114). Termasuk tidak adanya 
pengakuan akan hak-hak individual kewarganegaraan. Pada saat yang sama selalu mengemuka adanya perbedaan budaya, etnis dan agama.

\section{Masa Depan Islam di Papua Barat}

Ada kesulitan mendasar pada penentuan identitas personal sebagai seorang muslim di negara mayoritas sekaligus sebagai muslim di wilayah minoritas seperti Indonesia. Adanya sebuah gagasan untuk mewujudkan pendidikan dan pembinaan sebagai kata kunci penyelesaian masalah ini (Hammond,1988: 10). Sebagai fenomena yang tidak statis tetapi berjalan dalam ruang sebagai suatu proses maka bisa saja identitas ini dibentuk berdasarkan konstruksi sosial. Secara internal, maka ada permasalahan yang berhubungan dengan identitas diri. Kadang muncul sebuah persepsi dimana ada nilai berbeda yang dianut jika dibandingkan dengan masyarakat yang berada dalam lingkungan sekitar.

Penelitian ini menunjukkan ada pertumbuhan dan perkembangan Islam secara signifikan berlangsung. Sementara ini, penerimaan masyarakat terhadap Islam sebagai agama juga tidak menunjukkan gejala yang kontraproduktif. Justru Islam dan budaya Papua secara bersama-sama kemudian mengalami pergandengan dalam beberapa hal. Ini menunjukkan bahwa akan muncul kekuatan sosial dalam internal umat Islam sebagaimana ditunjukkan dengan dinamisnya pendidikan dan institusi umat yang dikembangkan secara swadaya. Pendidikan Islam secara dinamis berkembang. Tidak saja dalam proses kelembagaan tetapi penguatan kapasitas dan kontribusi luas di masyarakat (Wekke, 2012: 203). Pola-pola ini secara perlahan akan mendapatkan tempat dimana Islam di tanah Papua justru diperlakukan sebagai entitas bersama secara seimbang dan proporsional (Machacek, 2003:145). Maka, keberlangsungan Islam akan menemukan penghargaan, walaupun dalam kondisi minoritas. Dengan demikian akan muncul sebuah tanggung jawab untuk mengembangkan pola hubungan dengan mayoritas secara ramah, produktif dan humanis. Kekerasan atas nama agama dalam dua dekade terakhir di pelbagai wilayah Indonesia, tidak diinginkan terjadi di Papua (Klinken, 2007: 12). Sebab dipandang korbannya justru adalah keluarga sendiri (Bertrand, 2004: 5).

Dalam penelitian ini digambarkan, muslim Papua Barat secara aktif memperjuangkan keterlibatan, partisipasi dan peran serta di lingkungan muslim untuk membentuk pendidikan bagi generasi muslim. Hasil pendidikan dari lembaga yang berkembang mulai dari tingkatan pendidikan usia dini sampai ke jenjang pendidikan tinggi diharapkan akan melahirkan sosok 
pribadi muslim, terbentuknya keluasan wawasan dan kedalaman pengetahuan dalam mengamalkan ajaran agama. Dengan menguatnya kapasitas seperti ini, maka posisi umat Islam akan mendapatkan apresiasi dari kalangan umat lain. Pengakuan yang ada saat ini menunjukkan adanya perlakuan yang harmonis dan saling membutuhkan dengan elemen lain. Penunjukan sebagai pimpinan politik dalam skala provinsi, begitu pula di tingkatan kota dan kabupaten menunjukkan adanya kepercayaan dan dukungan dari kelompok lain. Berarti walaupun minoritas, tetapi umat Islam justru mendapatkan perlakuan yang manusiawi serta mendapatkan keutamaan secara bersama-sama dengan kelompok lain. Apa yang dicapai ini akan tetap bertahan jika didukung dengan adanya kualitas yang memadai, kontribusi dalam pendidikan dan pelatihan, dan peran sosial tanpa memandang kepentingan internal semata-mata.

\section{Simpulan}

Berdasarkan uraian di atas, maka kesimpulan penelitian ini bahwa muslim di Papua Barat ada dua hal yang menjadi temuan utama penelitian yaitu tradisi dan keberagaman. Pada aspek yang pertama, umat Islam berusaha untuk mempertahankan identitas sesuai dengan tuntunan beragama. Kehidupan sosial yang berlangsung dalam aktivitas sehari-hari, senantiasa terlaksana sebagai keberlangsungan tradisi yang sudah ada sebelumnya. Dengan pembentukan lembaga, maka berlangsung secara otomatis peran dan pola kepemimpinan. Ini merupakan kebutuhan komunitas untuk menjalin komunikasi sekaligus sebagai perwakilan dalam keterlibatan dengan kelompok masyarakat lainnya. Selanjutnya penguatan kapasitas individu seorang muslim dilakukan melalui pembentukan lembaga pendidikan yang didorong oleh semangat belajar. Walaupun ini dimaksudkan untuk kalangan internal tetapi beberapa kelompok masyarakat juga mempercayakan pendidikan keluarga mereka ke lembaga pendidikan Islam.

Sementara aspek yang melengkapi adalah keberagaman dalam kehidupan. Dengan tumbuhnya kelompok agama dan etnis yang plural, maka terjadi interaksi. Kemajemukan ini kemudian memunculkan simbol-simbol yang berbeda. Namun demikian kultur primordial masing-masing dapat dijembatani dengan adanya kepentingan untuk mewujudkan harmoni di antara elemen masyarakat. Kesadaran beragama secara kelompok kemudian mendorong masing-masing umat beragama untuk senantiasa mengakui keberagaman sekaligus upaya menjalin dialog. Justru dengan keberagaman itu menjadi kekuatan ketika penghargaan terhadap kelompok lain menjadi acuan utama. 
Interaksi sosial antar pemeluk agama jika berlangsung dalam koridor yang saling mengapresiasi pada perkembangannya akan menjadi aset. Keberagaman inilah yang menjadi salah satu nilai penting umat Islam di Papua Barat.

\section{Daftar Pustaka}

Abdullah, Amin. 1996. Studi Agama: Normativitas atau Historisitas? Yogyakarta: Pustaka Pelajar.

Al Alusi, Mahmud Syukri. Tth. Bulugh al-Arab fi Ma'rifah Ahwal al-Arab. Juz I. Cet. 2. Libanon: Dar al Kutub al Ilmiyyah.

Andaya, L. Y. 1993. The World of Maluku. Manoa: Hawaii University Press.

Arnold, Thomas W. 1995. The Preaching of Islam: A History of the Propagation of the Muslim Faith. New Delhi: Low Price Publications.

Badan Pusat Statistik Papua. 2007. Papua dalam Angka 2006. Jayapura: BPS Provinsi Papua.

Bertrand, Jacques. 2004. Nationalism and Ethnic Conflict in Indonesia. New York: Cambridge University Press.

Bradford, Jesse William. 2008. American/Muslim: Reactive Solidarity, Identity Politics, and Social Identity Formation in the Aftermath of September 11 [Disertasi]. Boston: Harvard University.

Bruinessen, Martin Van. 1995. Kitab Kuning Pesantren dan Tarekat Tradisi-Tradisi Islam di Indonesia. Bandung: Mizan.

Budiwanti, Erni. 2000. Islam Sasak. Yogyakarta: LKiS.

Charmaz, K. 1983. The Grounded Theory: An Explication and Interpretation. Dalam R. Emerson (penyunting), Contemporary Field Research. Boston: Little, Brown.

El Kacimi, Said. 2008. Identity and Social Integration: Exploratory Study of Muslim Immigrants in The United States [Disertasi]. San Diego: Claremont Graduate University.

Geertz, Clifford. 1960. The Religion of Java. New York: Free Preys.

Geertz, Clifford. 1973. The Interpretation of Cultures. New York: Basic Books.

Giddens, Anthony. 1989. Sociology. Cambridge: Polity Press.

Habermas, Jurgen. 1983. The Theory of Communication Active. Boston: Beacon Press. 
Hamka. 1981. Sejarah Umat Islam. Jakarta: Bulan Bintang.

Hammond, Philip E. 1988. Religion and The Persistence of Identity. Journal for the Scientific Study of Religion. Vol. 27, No. 1: 1-11.

Hefner, Robert W. 1985. Hindu Javanese: Tengger Tradition and Islam. Priceton, New Jersey: Priceton University Press.

Hewer, Chris. 2001. School for Muslims. Oxford Review of Education. Vol. 27, No. 4: 515-527.

Huzain, Muhammad. 2011. Perilaku Bom Bunuh Diri dengan Atas Nama Agama (Jihad) dalam Perspektif Filsafat Islam. Sorong: Pustaka Rafana STAIN Sorong.

Klinken, Gerry Van. 2007. Communal Violence and Democratization in Indonesia. London: Routledge.

Loobuyck, Patrick. 2005. Liberal Multiculturalism A efence of Liberal Multicultural Measures without Minority Rights. dalam Ethnicities. Vol. 5, No. 1.

Machacek, David W. 2003. The Problem of Pluralism. Sociology of Religion. Vol. 64, No. 2: 145 - 161 .

Moore, Kathleen. 2007. Muslim in the United States: Pluralism Under Certain Circumtances. Annals of The America Academy of Political and Social Sciences. Vol. 612.

Mujahidah. 2010. Analisis Terhadap Interaksi Sosial antar Pemeluk Agama dan Etnis di Kota Sorong. Sorong: Pustaka Rafana STAIN Sorong.

Mulkan, Abdul Munir. 2001. Dilema Manusia Dengan Diri dan Tuhan. Dalam Th. Sumartana (ed.) Pluralis, Konflik dan Pendidikan Agama di Indonesia. Yogyakarta: Pustaka Pelajar.

Mulkan, Abdul Munir. 2007. Satu Tuhan Seribu Tafsir. Yogyakarta: Kanisius.

Muller, Kal. 2008. Mengenal Papua. Jakarta: Daisy World Books.

Onim, Jusuf Frederik. 2006. Islam dan Kristen di Tanah Papua: Meniti Jalan Bersama Hubungan Islam-Kristen dalam Sejarah Penyebaran dan Perjuampaanya di Wilayah Semenanjung Onin Fakfak. Bandung: Jurnal Info Media.

Sappe, Sukman. 2010. Dakwah Islam di Kabupaten Raja Ampat Suatu Tinjauan Teologis. Sorong: Pustaka Rafana STAIN Sorong. 
Strauss, Anselm dan Juliet Corbin. 1994. Grounded Theory Methodology: An Overview. Dalam Norman K. Denzin dan Yvonna S. Lincoln (ed.) Handbook of Qulitative Research. Thousand Oaks: SAGE Publications.

Sunatar, Bambang. 2011. Tokoh Agama dan Politik (Studi Kasus Keterlibatan Tokoh Agama dalam Politik di Sorong). Sorong: STAIN Sorong.

Taylor, James B. 1993. The Naturalistic Research Approach. Dalam Richard M. Grinnel. Social Work Research and Evaluation. Edisi keempat. Itasca: F. E. Publishers, Inc.

Tim Peneliti Purbakala Irian Jaya. 1996. Laporan Penelitian Arkeologi Islam di Kecamatan Kokas Kabupaten Fakfak Irian Jaya. Jayapura: Proyek Penelitian Purbakala Irian Jaya.

Utrech, Ernst. 1986. Muslim and Military in Indonesia. Dalam Hering B. B., Studies on Indonesian Islam, hlm. 37-50. Quensland, Australia: Center for Asian Studies James Cook University.

Wekke, Ismail Suardi dan Yuliana Ratna Sari. Tifa Syawat dan Entitas Dakwah dalam Budaya Islam: Studi Suku Kokoda Sorong Papua Barat. Jurnal Kajian Budaya Islam Thaqafiryat. Vol. 13, No. 1: 163-186.

Wekke, Ismail Suardi. 2011. Pendidikan Islam dan Pemberdayaan Masyarakat(Tinjauan Pendidikan Vokasional Pesantren Roudhatul Khuffadz, Sorong). Jurnal Kajian Islam Interdisipliner. Volume 10, Nomor 1: 25 - 53.

Wekke, Ismail Suardi. 2012. Pesantren dan Pengembangan Kurikulum Kewirausahaan: Kajian Pesantren Roudhatul Khuffadz Sorong Papua Barat. Jurnal Inferensi. Volume 6, No. 2: 203-226.

Weller, Paul. Adressing Religious Discrimination and Islamophobia: Muslim and Liberal Democracies, the Cae of the United Kingdom. Journal of Islamic Studies. Vol. 17, No. 3: 295 - 325.

Widjojo, Muridan S, dkk. 2009. Papua Road Map Negotiating the Past, Improving the Present and Securing the Future. Jakarta: LIPI Press.

Widodo, Slmaet. 2010. Yayasan Emeyodere dalam Pelayanan Pendidikan Masyarakat Kokoda di Kota Sorong. Sorong: Pustaka Rafana STAIN Sorong. 